\title{
Sodium Dodecyl Sulphate-Sodium Chloride Extraction of Penicillium stoloniferum Mycelium for Viral Double-stranded RNA
}

\author{
By E. B. LI L LEHO J, R. W. DETROY AN D C. W. HESS E L T I N E \\ Northern Regional Research Laboratory, Agricultural Research Service, \\ U.S. Department of Agriculture, Peoria, Illinois 61604, U.S.A.
}

(Received 2I May I973; revised I I July I973)

S U M M A R Y

\begin{abstract}
Incubation of mycelia of a virus-containing strain of Penicillium stoloniferum in a $\mathrm{I} \%$ sodium dodecyl sulphate $-4 \%$ sodium chloride (SDS-NaCl) solution liberated protein and deoxyribonucleic acid within the first hours, whereas ribonucleic acid (RNA) release continued through an extended period. Although transfer RNA (tRNA) was readily solubilized by the treatment, viral doublestranded RNA (dsRNA) was not detected in the extracellular lysate during the initial $6 \mathrm{~h}$ of incubation. After $24 \mathrm{~h}$ of treatment, mechanical disruption of the mycelia liberated some dsRNA; this procedure demonstrated the incomplete solubilization of viral nucleic acid in SDS-NaCl. Scanning electron micrographs of mycelium treated with a salt-detergent mixture showed a progressive reduction in structural integrity of fungal hyphae. However, hyphal tips appeared to remain morphologically intact during incubation.
\end{abstract}

\section{NTRODUCTION}

The antiviral substance obtained from fungal fermentations has been identified as the double-stranded RNA (dsRNA) core of virus-like particles (VLP's) (Stark, Kleinschmidt \& Probst, 1963; Lampson et al. 1967; Kleinschmidt, Ellis, Van Frank \& Murphy, 1968). In initial studies, the component was obtained from the culture medium of a Penicillium stoloniferum fermentation (Kleinschmidt \& Probst, I962; Stark et al. 1963). Shope (I953) detected antiviral material in the culture broth of another fungus, Penicillium funiculosum, and in addition he observed that the active substance could be extracted from the mycelium. Later studies verified the presence of the antiviral component exclusively in the mycelium of VLP-containing fungi during the growth phase, with subsequent release into the culture medium (Banks et al. 1968; Ellis \& Kleinschmidt, 1967). Several techniques have been employed for rupture of fungal mycelia and release of the VLP's (Shope, 1953; Banks et al. 1968; Cox, Kanagalingam \& Sutherland, 197I). Procedures have also been described for direct extraction of dsRNA from fungi, including incubation of mycelia in detergent-salt solutions (Lemke \& Ness, r970; Sutherland, Heath \& Bessell, I97I).

We have studied the detergent-salt-mediated release of nucleic acid and protein from mycelia of Penicillium stoloniferum NRRL 5267. The efficiency of extraction of dsRNA from mycelium incubated in sodium dodecyl sulphate (SDS) and sodium chloride has been determined. We have also examined the effect of SDS- $\mathrm{NaCl}$ incubation on the integrity of fungal mycelium. 


\section{METHODS}

Production, harvest and disruption of mycelia. Penicillium stoloniferum Thom NRRL 5267 (ATCC I4586) mycelia were produced in 2.81 Fernbach flasks containing $500 \mathrm{ml}$ of a glycerol-glucose $(0.5 \%$ ) medium (Stark, Kleinschmidt \& Probst, 1963), inoculated with a spore suspension, and incubated on a rotary shaker at $28^{\circ} \mathrm{C}$. Mycelia were harvested by filtration and washed with an equal volume of $0.0 \mathrm{I} \mathrm{M}^{-\mathrm{PO}_{4}}$ buffer, $\mathrm{pH} 7 \cdot 0$. The filtered mould was resuspended in $0.0 \mathrm{I} \mathrm{M}_{-} \mathrm{PO}_{4}$ buffer, $\mathrm{pH} 7.0$ ( $\mathrm{g}$ wet wt/ $/ 0 \mathrm{ml}$ ) before rupture. Mycelia were disrupted in a refrigerated Manton-Gaulin homogenizer at $5000 \mathrm{lb} / \mathrm{in}^{2}$ pressure, with recycling of the slurry for $3 \mathrm{~min}$. Cell debris was removed from the homogenate by centrifugation at $8000 \mathrm{~g}$ for $20 \mathrm{~min}$.

Isolation and determination of RNA, DNA and protein. Harvested mycelia (48 h) were suspended in an aqueous solution of $\mathrm{I} \% \mathrm{SDS}$ and $4 \% \mathrm{NaCl}$ and gently stirred with periodic sampling and centrifugation of the lysate at $8000 \mathrm{~g}$ for $10 \mathrm{~min}$. The clarified lysate supernatant was treated with 2 vols. of methanol and the precipitate collected by centrifugation at $3000 \mathrm{~g}$ for $10 \mathrm{~min}$. The pelleted material was redissolved in $0.2 \mathrm{M}$-sodium acetate and an equal volume of aqueous $90 \%$ phenol containing $0 . \mathrm{I} \%(\mathrm{w} / \mathrm{v})$ 8-hydroxyquinoline was added (Cox et al. 197I). The mixture was stirred for $\mathrm{I} 5 \mathrm{~min}$ at $25^{\circ} \mathrm{C}$ before centrifuging at $4000 \mathrm{~g}$ for $20 \mathrm{~min}$ at $4{ }^{\circ} \mathrm{C}$, and the RNA in the aqueous phase was freed from phenol by repeated precipitation (cold methanol, $\mathrm{v} / \mathrm{v}$ ) from $0.2 \mathrm{M}$-sodium acetate solution. The final precipitate was dissolved in a minimal volume of SSC (0. I5 $\mathrm{M}-\mathrm{NaCl}$ and $0.015 \mathrm{M}$-sodium citrate), $\mathrm{pH}_{7 \cdot 4}$. U.v. spectroscopy with a Beckman DB used a $\mathrm{I} \mathrm{cm}$ light path. Isolated RNA was separated electrophoretically on polyacrylamide gels $(2.4 \%)$ for $2.5 \mathrm{~h}$ at $6 \mathrm{~mA} /$ tube (Bozarth, Wood \& Mandelbrot, 1971). Gels were scanned on a Gilford linear transport system at $260 \mathrm{~nm}$. The concentration of viral RNA and tRNA in the SSC preparations was determined from electrophoretograms by integrating peak areas and comparing values obtained from known quantities of dsRNA and tRNA similarly separated.

Release of protein and nucleic acid was determined in the aqueous solution remaining after cellular material had been sedimented by centrifugation at $8000 \mathrm{~g}$ for $20 \mathrm{~min}$. Protein was determined by the Folin method (Lowry, Rosebrough, Farr \& Randall, 195I), DNA by the diphenylamine technique (Burton, 1956) and RNA by the orcinol reaction (Mejbaum, I939).

Scanning electron microscopy. Squares (I0 $\times$ I0 $\mathrm{mm}$ ) cut from glass microscope slides were placed on aluminium specimen stubs for mounting in the microscope. About $0.05 \mathrm{ml}$ of a thoroughly washed, diluted mycelial suspension ( $48 \mathrm{~h}$ cells) was spread over the surface of the mount, dried and coated with aluminium to a thickness of $15 \mathrm{~nm}$. Specimens were examined in a Cambridge Stereoscan mark II scanning electron microscope at an accelerating voltage of $20 \mathrm{kV}$; the final aperture was $200 \mu \mathrm{m}$ and the beam specimen angle $45^{\circ}$.

\section{R E S U L T S}

\section{Release of protein and nucleic acid from mycelia}

Penicillium stoloniferum mycelia $(48 \mathrm{~h}$ ) were suspended (I g wet $\mathrm{wt} / \mathrm{IO} \mathrm{ml}$ ) in an aqueous solution of $\mathrm{r} \% \mathrm{SDS}$ and $4 \% \mathrm{NaCl}$ for extraction tests. The suspension was gently stirred at $25{ }^{\circ} \mathrm{C}$ with incremental removal of $100 \mathrm{ml}$ samples, residual mycelium was sedimented by centrifugation, and methanol $(2 \times$ vol.) was added to the supernatant with subsequent centrifugal sedimentation of the precipitate and resuspension in $0.2 \mathrm{M}$-sodium acetate. The latter solution was tested for the presence of protein and nucleic acids (Fig. I). Release of 


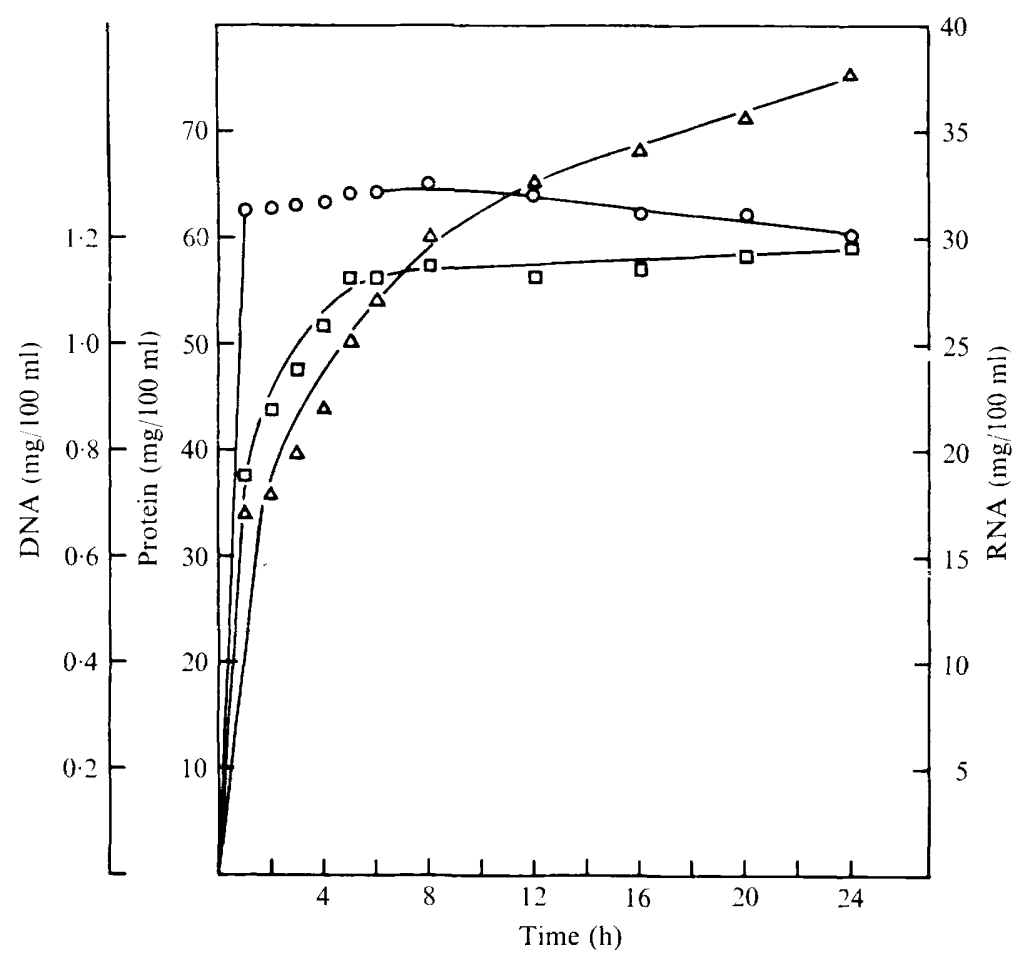

Fig. I. Time course of protein, DNA and RNA release from Penicillium stoloniferum mycelia during incubation in $\mathrm{I} \%$ sodium dodecyl sulphate (SDS) $-4 \% \mathrm{NaCl}$ solution. After $100 \mathrm{ml}$ of mycelial ( $\mathrm{g}$ wet $\mathrm{wt} / \mathrm{I} 0 \mathrm{ml}$ ) suspension was removed it was sedimented by centrifugation. Methanol ( $2 \times$ volume) was added to the supernatant and the precipitate was sedimented and resuspended in $0.2 \mathrm{M}$-sodium acetate. $\mathrm{O}$, Protein release determined by the Folin method; $\square$, DNA release determined by the diphenylamine method; $\triangle$, RNA release determined by the orcinol method.

protein from the mycelia was rapid (Fig. I, curve O), with essentially complete extraction of the solubilized fraction during the initial hour of the $24 \mathrm{~h}$ incubation. Slight reduction of the protein level during later stages of incubation probably represents gradual protein denaturation in the test solution with subsequent precipitation in the residual mycelium fraction. DNA was released from mycelia more slowly than protein, with the maximum level in the extracellular milieu occurring after $6 \mathrm{~h}$ of incubation (Fig. I, curve $\square$ ). RNA detected in solution did not reach a maximum during the $24 \mathrm{~h}$ treatment but at the end of the trial period was slowly increasing (Fig. I, curve $\triangle$ ).

Quantities of DNA, RNA and protein were determined in the aqueous phase and in mycelia after $24 \mathrm{~h}$ incubation in SDS- $\mathrm{NaCl}$ solution (Table I). Slightly less than half the total protein and RNA were released during the procedure and three-quarters of the DNA was solubilized. Fig. I shows that most of the release of macromolecules during SDS-NaCl incubation occurred in the initial $24 \mathrm{~h}$ period. The nucleic acid and protein remaining in the mycelium after incubation were therefore resistant to further detergent-salt extraction. 


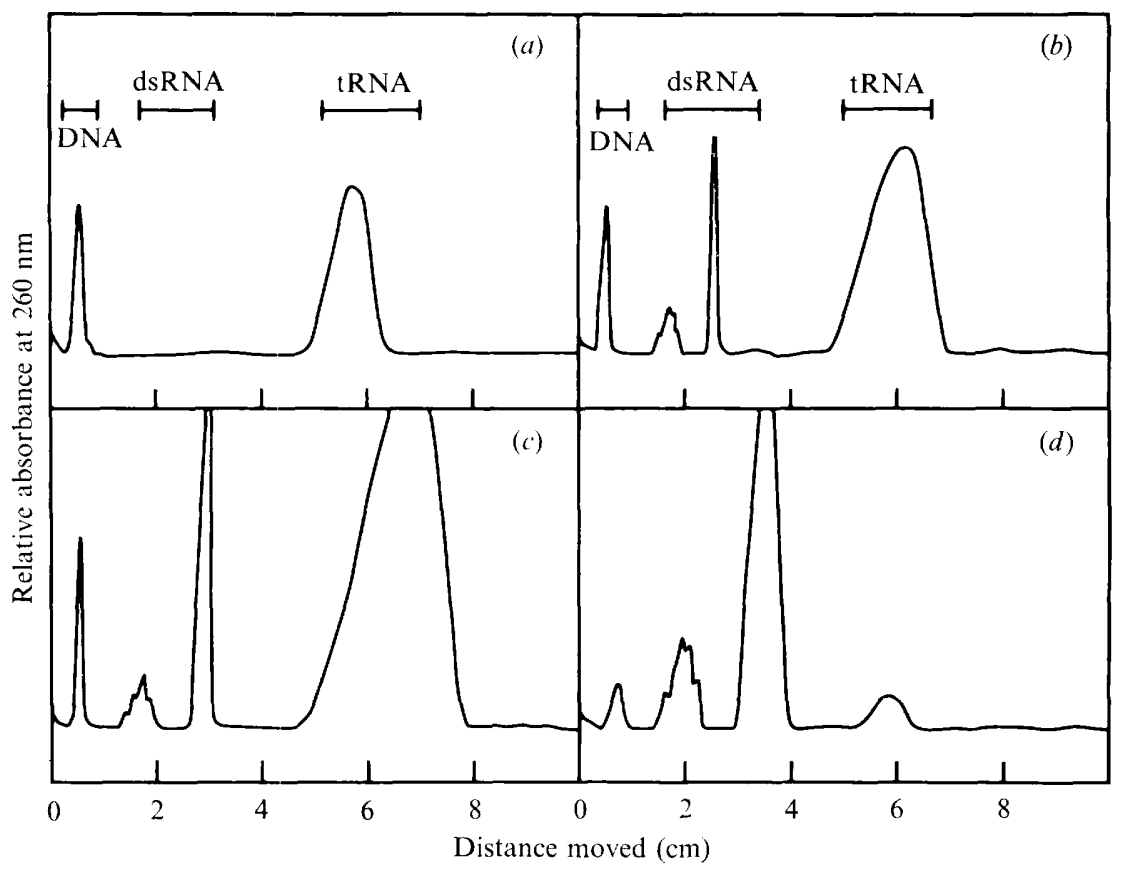

Fig. 2. Qualitative electrophoretic characterization of phenol-treated RNA fraction obtained from SDS-NaCl lysate and Manton-Gaulin homogenization of Penicillium stoloniferum mycelia. The final precipitate from phenol treatment was solubilized in SSC and added to polyacrylamide gels $(2.4 \%)$. Electrophoresis was carried out for $2.5 \mathrm{~h}$ at $6 \mathrm{~mA} /$ tube. Developed gels were scanned on a Gilford linear transport at $260 \mathrm{~nm}$. (a) Two-hour incubation in SDS- $\mathrm{NaCl}$ with subsequent phenol treatment of the supernatant from the lysate. (b) Manton-Gaulin homogenization of the mycelia treated for $2 \mathrm{~h}$ in SDS- $\mathrm{NaCl}$ with subsequent phenol treatment of the supernatant. (c) Incubation $(24 \mathrm{~h})$ in SDS-NaCl with subsequent phenol treatment of the supernatant from the lysate. (d) Manton-Gaulin homogenization of the mycelia treated for $24 \mathrm{~h}$ in SDS-NaCl with subsequent phenol treatrnent of the supernatant.

Table I. Extraction of protein and nucleic acid from Penicillium stoloniferum mycelia during incubation in $\mathrm{r} \%$ sodium dodecyl sulphate $(S D S)-4 \% \mathrm{NaCl}$ solution and subsequent MantonGaulin homogenization

Mycelia ( $75 \mathrm{~g}$ wet wt) were incubated in $750 \mathrm{ml}$ of SDS- $\mathrm{NaCl}$ for $24 \mathrm{~h}$ at $25^{\circ} \mathrm{C}$ with subsequent filtration, determination of the macromolecular levels in the filtrate, resuspension of the treated mycelia in 0.01 M- $\mathrm{PO}_{4}, \mathrm{pH}_{7} . \mathrm{O}$ (I 1), Manton-Gaulin homogenization of the treated mycelia, sedimentation of cell debris, and measurement of macromolecular levels in the supernatant. Values are means of three replicates.

\begin{tabular}{|c|c|c|c|c|c|c|}
\hline & \multicolumn{2}{|c|}{ Protein } & \multicolumn{2}{|c|}{ RNA } & \multicolumn{2}{|c|}{ DNA } \\
\hline & $\mathrm{mg}$ & $\begin{array}{l}\% \text { of } \\
\text { total }\end{array}$ & $\mathrm{mg}$ & $\begin{array}{l}\% \text { of } \\
\text { total }\end{array}$ & mg & $\begin{array}{l}\% \text { of } \\
\text { total }\end{array}$ \\
\hline $\mathrm{SDS}-\mathrm{NaCl}$ supernatant & 405 & 46 & 230 & 42 & $7 \cdot 8$ & 77 \\
\hline Manton-Gaulin homogenate & 480 & 54 & 313 & 58 & $2 \cdot 4$ & 23 \\
\hline
\end{tabular}

\section{Characterization of $\mathrm{RNA}$ released by $\mathrm{SDS}-\mathrm{NaCl}$}

An electrophoretic examination was made of the RNA fraction released by SDS-NaCl or mechanical disruption (Fig. 2). After $2 \mathrm{~h}$ of SDS-NaCl treatment there appeared to be exclusive release of a single RNA entity; the substance(s) exhibited mobility essentially 
Table 2. Time course of $d s R$ A release from Penicillium stoloniferum mycelia during incubation in I \% $\mathrm{SDS}-4 \% \mathrm{NaCl}$

Mycelia (IOO g wet wt) were incubated in 11 of SDS- $\mathrm{NaCl}$ at $25^{\circ} \mathrm{C}$ with subsequent filtration, phenol treatment of the supernatant, solubilization of the nucleic acid in SSC, and electrophoretic separation of the RNA constituents on polyacrylamide gels. The AU units (absorbance units at $260 \mathrm{~nm}$ in a I cm cell) are composite values from each sample, obtained by computation of the area under the viral dsRNA electrophoretogram peaks from known volumes.

$\begin{array}{cc}\begin{array}{c}\text { SDS } \\ \text { treatment } \\ \text { (h) }\end{array} & \begin{array}{c}\text { Viral } \\ \text { dsRNA } \\ \text { (AU units) }\end{array} \\ 0.25 & - \\ 0.50 & - \\ 2 & - \\ 3 & - \\ 6 & 0.3 \\ 8 & 0.4 \\ 12 & 5.0 \\ 24 & 46.0\end{array}$

identical to the reference tRNA from yeast with a mol. wt of 35000 (Fig. 2 a). MantonGaulin homogenization of the mycelia recovered after $2 \mathrm{~h}$ released an RNA fraction characterized by Fig. $2(b)$. This fraction contained, in addition to tRNA, the dsRNA components identified as the nucleic acid cores of the two virus-like particles from the mould (Bozarth et al. 197I). The lowest mobility group of multiple peaks contained molecules ranging in mol. wt from $\mathrm{I} \cdot 10 \times 10^{6}$ to $0.89 \times 10^{6}$ daltons, whereas the largest viral dsRNA band contained a molecule of $0.23 \times 10^{6}$ daltons. The nucleic acid fraction solubilized during $24 \mathrm{~h}$ SDS- $\mathrm{NaCl}$ incubation contained dsRNA viral constituents and tRNA (Fig. $2 c$ ). Further disruption of the mycelia after the $24 \mathrm{~h}$ treatment released predominantly dsRNA with much less tRNA (Fig. $2 d$ ). These tests demonstrated that tRNA was preferentially released from the mycelia early in the incubation with detergent and salt. After $24 \mathrm{~h}$ in SDS- $\mathrm{NaCl}$ some of the dsRNA remained associated with the cellular fraction.

The release of dsRNA from mycelia was further examined by determining the amount of the substance solubilized at various time intervals in detergent-salt solution (Table 2). No detectable quantity of dsRNA was released during the initial $3 \mathrm{~h}$. Limited amounts of the nucleic acid were detected after 6 and $8 \mathrm{~h}$ incubation with about a tenfold increase in the solubilized viral RNA between 8 and $\mathrm{I} 2 \mathrm{~h}$ and a similar multiple increase between $\mathrm{I} 2$ and $24 \mathrm{~h}$. The total AU (absorbance units at $260 \mathrm{~nm}$ in a $\mathrm{I} \mathrm{cm}$ cell) present in the SSC solution before electrophoretic separations was compared with the aggregate viral dsRNA AU values observed after resolution of the nucleic-acid fractions. This test showed that more than $80 \%$ of total AU in SSC was released during the initial $6 \mathrm{~h}$ of SDS-NaCl incubation, but there was little viral RNA solubilized during the same test period. Of the total $\mathrm{AU}$ in SSC at the end of the experiment ( $24 \mathrm{~h}$ in SDS-NaCl), $12 \%$ was viral dsRNA.

\section{Changes in fungal cells induced by $\mathrm{SDS}-\mathrm{NaCl}$}

The extent of mycelial lysis achieved during the $24 \mathrm{~h} \mathrm{SDS}-\mathrm{NaCl}$ treatment was examined by determination of viability at the end of the trial. Samples of extraction medium (sterile incubation) were transferred to nutrient agar plates; after 3 days at $28^{\circ} \mathrm{C}$ abundant Penicillium stoloniferum growth appeared. Microscopic examination of mycelia before and after treatment revealed no characteristic conidial forms. Therefore, some of the mycelium maintained viability during salt-detergent incubation. 

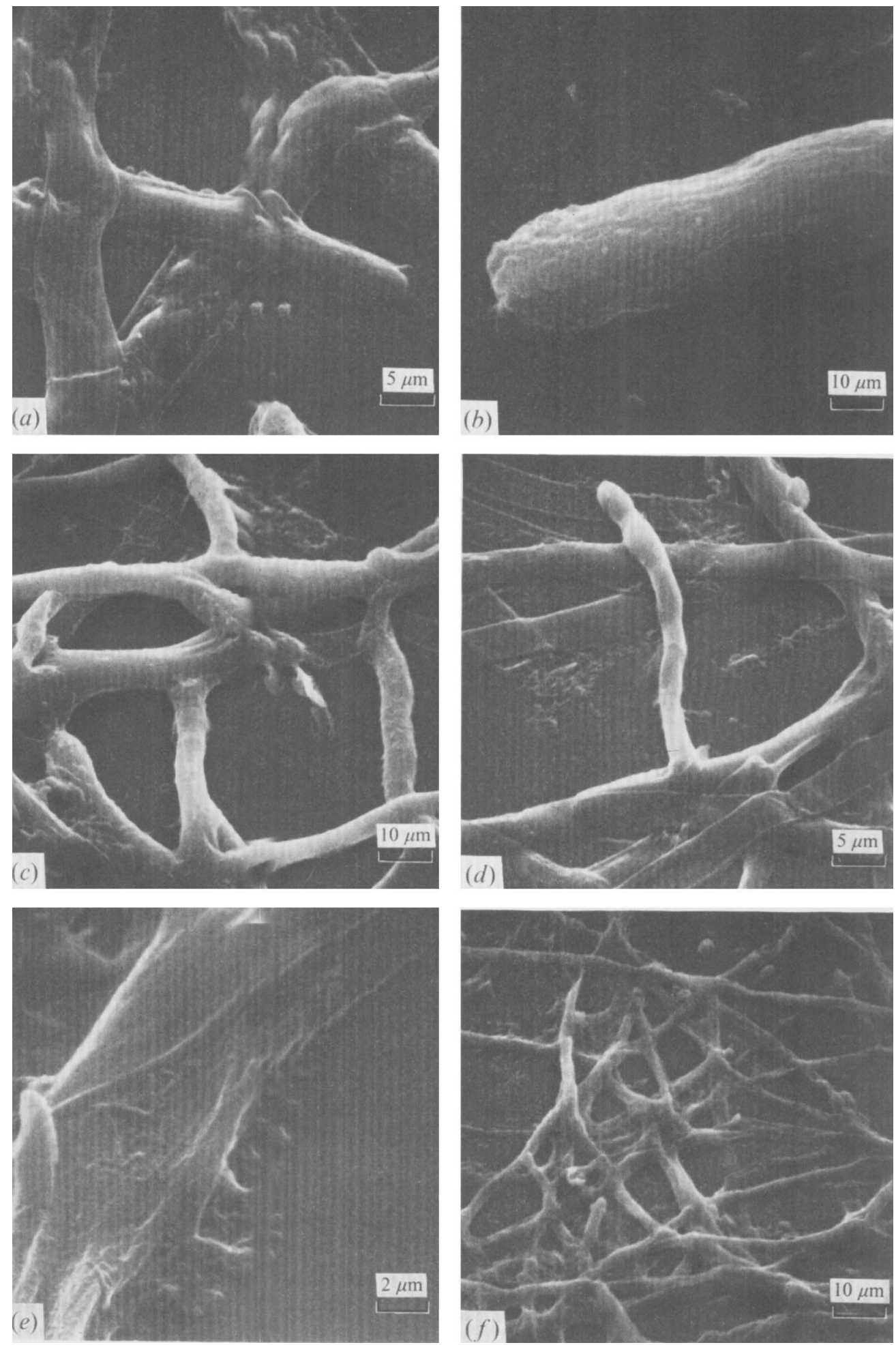

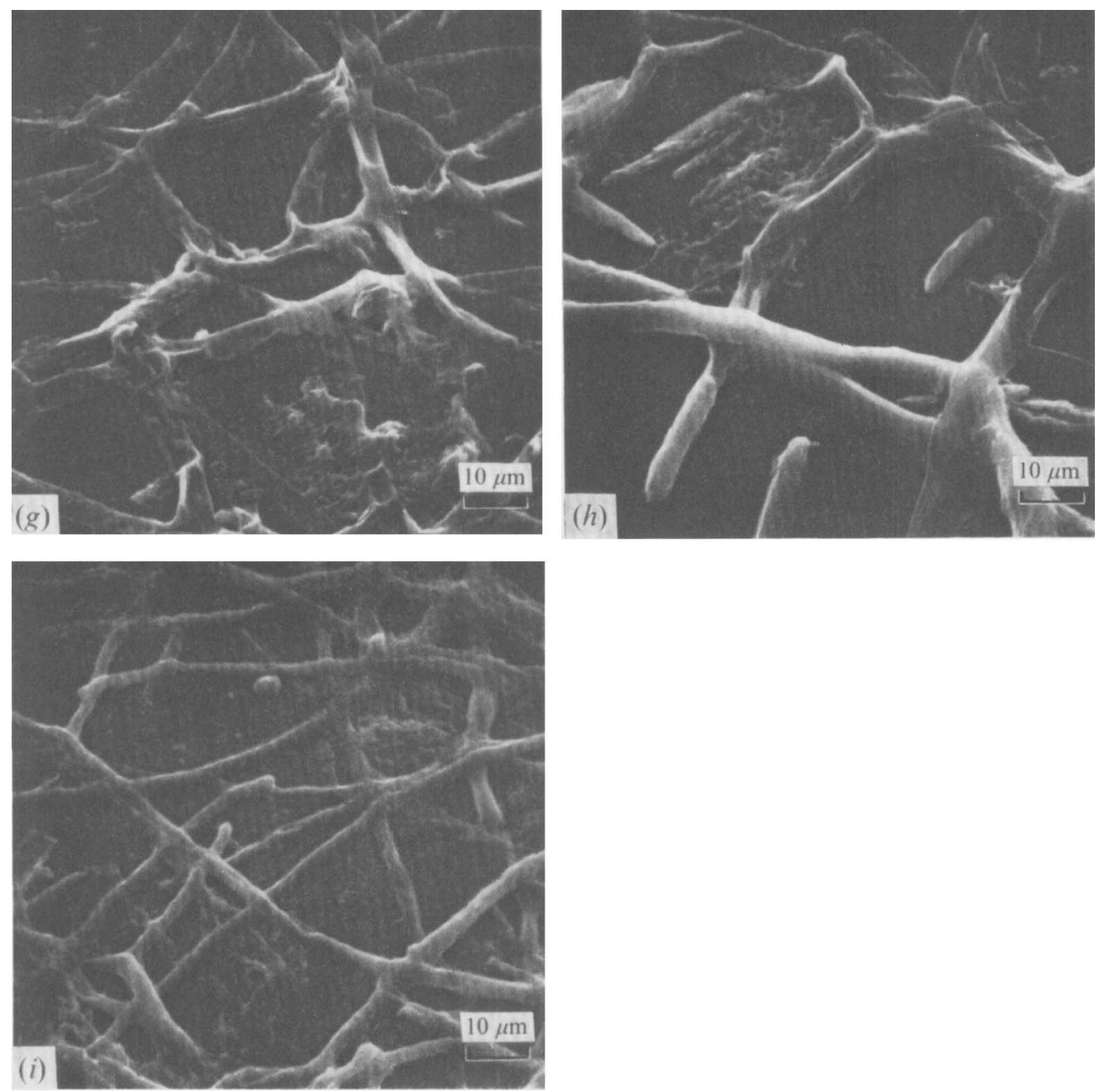

Fig. 3. Scanning electron micrographs of Penicillium stolonifertum mycelia incubated in $1 \%$ SDS -4 $4 \% \mathrm{NaCl}$ or $0.01 \mathrm{M}-\mathrm{PO}_{4}, \mathrm{pH}_{7} \cdot \mathrm{O}$. (a) Untreated mycelia, (b) hyphal tip of untreated mycelia, (c) mycelia after $\mathrm{I} \mathrm{h}$ in SDS- $\mathrm{NaCl},(d)$ mycelia after $8 \mathrm{~h}$ in SDS- $\mathrm{NaCl},(e)$ debris associated with hypha treated for $8 \mathrm{~h}$ in SDS- NaCl, $(f)$ mycelia after $8 \mathrm{~h}$ in $\mathrm{PO}_{4}$ buffer, $(g, h)$ mycelia after $12 \mathrm{~h}$ in $\mathrm{SDS}-\mathrm{NaCl}$ and $(i)$ mycelia incubated for $\mathrm{I}_{2} \mathrm{~h}$ in $\mathrm{PO}_{4}$ buffer.

Since a portion of the mycelium was apparently not losing critical macromolecules during the SDS- $\mathrm{NaCl}$ treatment, incubated mycelial fractions were examined in a scanning electron microscope to elucidate morphological variations. Fig. 3(a) shows the typical morphology of untreated mycelium. Although high-vacuum fixation partially collapsed the mycelium, it is clear that cytoplasmic contents remained in the intact hyphae. Fig. $3(b)$ is a slightly higher magnification of an untreated hyphal tip and reveals the apparent rigidity of the extremity. After $\mathrm{I} h$ in $\mathrm{I} \% \mathrm{SDS}-4 \% \mathrm{NaCl}$ (Fig. $3 \mathrm{c}$ ), a few of the hyphae appear weakened, and fixation produces some casing-like structures of mycelial wall seemingly devoid of protoplasm. After $8 \mathrm{~h}$ in SDS-NaCl there was a large increase in the number of empty hyphae (Fig. $3 d$ ). However, hyphal tips appeared less liable to collapse than the mycelium behind the extremities. This micrograph also shows some amorphous debris that seemed to 
be cellular material extruded during the high-vacuum fixation. Fig. $3(e)$ presents a higher magnification of debris in close association with the mycelium. A control mycelial incubation was carried out in $0 \cdot 0 \mathrm{I} \mathrm{M}-\mathrm{PO}_{4}$ buffer, $\mathrm{pH} 7 \cdot 0$, to provide a comparison between the morphological variations. After $8 \mathrm{~h}$ in buffer, almost all the hyphae remained structurally rigid (Fig. $3 f$ ). Fig. $3(g)$ and $(h)$ shows the typical hyphal morphology after $\mathrm{I} 2 \mathrm{~h}$ in SDS$\mathrm{NaCl}$; essentially all the mycelial strands appear empty, but the hyphal tips remain distended. Mycelia incubated in buffer for $12 \mathrm{~h}$ had few empty hyphae, and inflated mycelia (Fig. $3 i$ ) contrasted with the collapsed wall structures observed after SDS-NaCl treatment for a similar period (Fig. $3 g, h$ ).

\section{I S C US S I O N}

Experiments were carried out to gain information on the selective release of viral dsRNA from Penicillium stoloniferum mycelia. Both protein and DNA were rapidly released when mycelia were incubated in I \% SDS- $4 \% \mathrm{NaCl}$, whereas RNA release continued longer. Specific determination of RNA fractions solubilized during the SDS-NaCl treatment showed that tRNA was rapidly released, chiefly during the first few hours of incubation. The dsRNA, however, did not appear in the aqueous phase of the lysate before $6 \mathrm{~h}$; after $24 \mathrm{~h}$ of incubation a significant portion of the viral RNA remained associated with the insoluble cell fraction. The failure to solubilize all the viral nucleic acid in a detergent-salt solution indicated that either the molecules were tightly bound to cytoplasmic structure(s) or they were retained in parts of the mycelium which were not being lysed by the treatment. Tests of the structural strength of the hyphal strand after detergent-salt treatment indicated that hyphal tips remained rigid, whereas older hyphae in the mycelium were readily emptied. In addition, after $24 \mathrm{~h}$ of SDS- $\mathrm{NaCl}$ incubation mycelia were viable, an observation which provides further evidence that parts of the mycelium retain their integrity. Some of the viral dsRNA located within the mycelium could be solubilized by a detergent-salt treatment, but a fraction of the viral nucleic acid appeared to be associated with hyphal components that were not disrupted by the procedure. Our scanning electron micrographs suggest that the resistant components were located at the hyphal tips. Therefore, we tentatively conclude that the tip regions of fungal hyphae contain viral nucleic acid.

\section{R EF ER E N C ES}

Banks, G. T., Buck, K. W., Chain, E. B., Himmelweit, F., Marks, J. E., Tyler, J. M., Hollings, M., LAST, F. T. \& Stone, O. M. (1968). Viruses in fungi and interferon stimulation. Nature, London 218, $542-545$.

Bozarth, R. F., Wood, H. A. \& Mandelbrot, A. (I97I). The Penicillium stoloniferum virus complex: two similar double-stranded RNA virus-like particles in a single cell. Virology 45, 516-523.

Burton, K. (1956). A study of the conditions and mechanism of diphenylamine reaction for the colorimetric estimation of deoxyribonucleic acid. Biochemical Journal 62, 315-324.

Cox, R. A., Kanagalingam, K. \& Sutherland, E. S. (I97I). Thermal denaturation in acidic solutions of double-helical ribonucleic acids from virus-like particles found in Penicillium chrysogenum. Biochemical Journal 125, 655-665.

Ellis, L. F. \& KLEINSCHMid, W. J. (1967). Virus-like particles of a fraction of statolon, a mould product. Nature, London 2r5, 649-650.

Kleinschmidt, W. J., Ellis, L. F., VAN Frank, R. M. \& MURPhy, E. B. (I968). Interferon stimulation by a double-stranded RNA of a mycophage in statolon preparations. Nature, London 220, 167-168.

KLeinschmid, W. J. \& Probst, G. W. (1962). The nature of statolon, an antiviral agent. Antibiotics and Chemotherapy 12, 298-309.

lampson, G. P., Tytell, A. A., Field, A. K., Nemes, M. M. \& Hilleman, M. R. (I967). Inducers of interferon on host resistance. Proceedings of the National Academy of Sciences of the United States of America $58,782-789$. 
LEMKe, P. A. \& Ness, T. M. (1970). Isolation and characterization of a double-stranded ribonucleic acid from Penicillium chrysogenum. Journal of Virology 6, 8I3-8I9.

Lowry, O. H., Rosebrough, N. J., Farr, A. L. \& Randall, R. J. (I95I). Protein measurement with the Folin phenol reagent. Journal of Biological Chemistry I93, 265-275.

Mejbaum, W. (1939). Über die Bestimmung kleiner Pentosemengen, insbesondere in Perivaten der Adenylsäure. Hoppe-Seylers' Zeitschrift für physiologische Chemie 258, I17-126.

Shope, R. E. (1953). An antiviral substance from Penicillium funiculosum. Journal of Experimental Medicine $97,60 I-625$.

Stark, W. M., Kleinschmidt, W. J. \& Probst, G. W. (1963). Statolon production by submerged culture fermentation. U.S. Patent 3 I08047, assigned Eli Lilly \& Co.

Sutherland, E. S., Heath, I. \& Bessell, C. J. (I97I). Production of double stranded ribonucleic acid. U.S.Patent 35973 I 8 , assigned Glaxo Laboratories Ltd. 